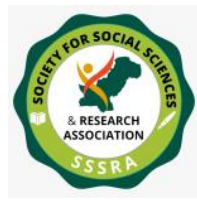

Pak. Journal of Int'L Affairs, Vol 4, Issue 1 (2021) Shortage of Construction Materials ...

\title{
Shortage of Construction Materials: A Case Study of Lahore, Islamabad and Peshawar, Pakistan
}

\author{
Mirza Ali \\ Directorate of Works \\ FATA University \\ Dara Adam Khel, FR Kohat, Pakistan \\ mirza.ali@fu.edu.pk \\ Dr. Sharif Ullah Jan \\ Department of Management Sciences \\ FATA University \\ Dara Adam Khel, FR Kohat, Pakistan \\ sharifullah.jan@fu.edu.pk \\ Shamshad Ali \\ Sarhad University of Science and Information Technology \\ Peshawar, Pakistan \\ shamshad.btech@suit.edu.pk
}

Abstract:

The fundamental focus of this qualitative study is to explore the contributing factors responsible for construction material shortage specifically in major cities of Pakistan's such as Lahore, Peshawar, and Islamabad. Further, the study has concentrated to discover the potential remedies to overcome the barriers resulting in a shortage of construction material availability. Data sampling methods are utilized to apprehend the participant's opinion. The participant's opinions were recorded to make them efficiently analyze through inductive thematic investigation. For sound results, the current condition of material shortage, relevant reasons, and deficiency of key items are examined in detail. The research findings proposed that the unavailability of materials is associated with the deficiency of a customary delivery system, fluctuations in demand, complications in the import of materials, significant expense, limited share portion in raw material, constrained suppliers of crude material, political clashes, administrative limitations, and maintenance of realistic prices. The result obtained, the recommended remedies are to extend flexibility and guideline for the manufacturers, the maintenance of realistic prices, and boosts the record control system, improvement in stock control framework, and establishment of a reserve system in the country. This 


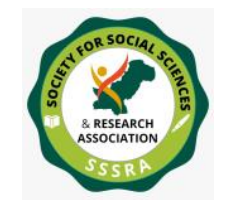

Pak. Journal of Int'L Affairs, Vol 4, Issue 1 (2021) Shortage of Construction Materials ...

study believes in contributing to the shortage of construction materials: a case study of Lahore, Islamabad, and Peshawar, Pakistan

Keywords: Material shortage, reasons, public sector, construction projects

\section{Introduction and Literature Review}

According to American Standard Testing Material (ASTM), the obtainability of nontoxic, genuine, and crucial construction materials is important to achieve the maximum standard for human life (Kim et al., 2018). However, frequent materials shortages have been recognized globally (Kim et al., 2016). In 2019, the American Standard Testing Material (ASTM), indicated that nearly 2 billion peoples having no access to basic and living safe construction materials (Sweis et al., 2008) causing inferior construction and costly financial implication. The ASTM described material shortage as the supply of materials, construction products, and special material identified as essential by the construction industry is insufficient to meet government construction project's needs (Frimpong et al., 2003). Further, it says that material deficiency implies a period when the interest or assessed interest for the material outperforms the gracefulness of the material (Rahman et al., 2012). Material deficiencies are not a modern issue; however, their scope and extent have prompted dramatically in recent years (Hwang et al., 2013). The American Society of Civil Engineers (ASCE) announced that before the end of 2019, construction materials were in short supplies (Iyer \& Jha, 2005). In 2018, a Canadian report uncovered that there were deficiencies of just about 352 construction items every year (Abdul-Rahman et al., 2006). The reports from Europe, Africa, Brazil, Fiji, and the Middle East additionally assigned that material deficiencies were capable intermittently and the pattern has been developing quickly (Wei, 2010; Shree, 2007). Materials deficiencies speak to a perceptible public construction industry danger, influencing any class of development material (Assaf et al., 1995). Construction materials deficiencies have made huge development deterrents and its outcomes include valuable contrasts, security issues arranged outcomes, material mistakes, money-related consequences, higher material costs, expanded work costs, and amplified cost for the work (Rehman et al., 2011). Other than this, wholesalers, merchants, and constructors may encounter minimal benefit, degenerate status, and hazardous associations with the customers and specialists (Mahmood, 2001). There are numerous different random and various reasons for the materials deficiencies which change from region to region. The essentials paying to an interruption in the accessibility of materials summed up in ASTM and ASCE reports incorporate: (1) fabricating issues and administrative issues; (2) willful reviews; (3) crude materials flexibly issue; (4) variation in item definition or producer; (5) constrained materials creation, gracefully and allotment; (6) industry combinations; (7) makers' choices and financial matters; (8) cataclysmic events; (9) divided interest and moves in 


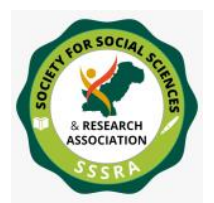

project practice; (10) dark market; (11) poor stock control; (12) non-conventional merchants, and (13) limited material item dissemination and designation.

Pakistan is a middle-income nation and is probably going through common material deficiencies, where a minor level of the all-out open part construction projects spending plan is distributed for construction material and construction practice. Pakistan has a commonplace material gracefully framework. Materials made in construction enterprises are migrated to merchants and wholesalers, loaded at retail arrangements for construction projects, recommended by material specialists, circulated at construction projects, and in the long run given away to and taken by the customers (Ahmad \& Mohamad, 2014). The hugeness of crude material, manufacturing, stockpiling, conveyance, and offer of material in the nation are controlled under the PEC Demonstration, 1976 (XXXI of 1976), and NTC Act, 2015. The government has constituted a board for obtaining life comfortable materials that specifically deal with material shortages. Despite the nearness of administrative experts in Pakistan, material deficiencies are activated by tenacious arrangement hole between the development division and the material business, absence of execution of existing strategies, hurried procedure of enrollment, inability to control value, absence of online warning framework, and deficient condemning practices for rebellious partners. Various reports from Pakistan uncovered that there were extreme deficiencies of development materials, Hi-tech instruments, aluminum industry, sanitary ware materials, raw materials of Mild Steel (MS), Galvanized Iron (GI), Cast Iron (CI), High Tensile (HT) steel reinforcement material because of administrative and gracefully side obstacles. In this current investigation, 55\% of Designers and Building Technologists working in the tertiary consideration open division activities of Lahore reacted that they have confronted deficiencies of different brands of materials, $89 \%$ of Engineers and $93.2 \%$ Building Technologists revealed that material deficiencies prompted antagonistic consequences for open part extends with a cost invade, challenges of development, second rate development, broadened tasks, and increment overwhelm cost. The International Standard Testing Material (ISTM) proposed nation explicit studies to investigate the contributing elements and potential answers to maintain a strategic distance from material deficiencies. Exceptional, proof put together exploration information concerning material deficiencies is missing and extremely restricted investigations are directed in Pakistan. Through the available literature, material shortages in Pakistan is mainly linked to regulatory and supply-side issues and major stakeholders were the public sector organizations and material manufacturers. Yet, to date, there is no previous research studies from Pakistan appeared to gain the perspective of these important issue. Furthermore, the higher occurrence of particular construction brand shortages as compared with generics, there was a dearth of data regarding the issue of particular brand shortages and their associated factors. Hence, this study was conducted to fill the research gap and provide a detailed multi-perspective understanding of material shortages at different levels in the supply chain. The researcher emphasized discovering the particulars material shortage crises through a qualitative study in Pakistan 
to identify the underlying causes and possible solutions to overcome on the issues. The particular material shortages were also taken into account as a secondary objective of research study.

\section{Research Methodology}

The focus of this research study is Pakistan, a state located in South Asia. The extent of the examination inside Pakistan is restricted to three significant urban areas named Lahore, Islamabad, and Peshawar, contingent upon the accessibility of the most appropriate key witnesses. Islamabad is the capital of Pakistan while Lahore is the capital city of the Punjab province and one of the most populated and biggest urban areas in the nation. Similarly, Peshawar is the capital of the Khyber Pakhtunkhwa province of Pakistan and is considered among the major cities of Pakistan. In Pakistan, the Ministry of Housing and Works is responsible for the management and regulation of supply materials. 
Pak. Journal of Int'L Affairs, Vol 4, Issue 1 (2021) Shortage of Construction Materials ...

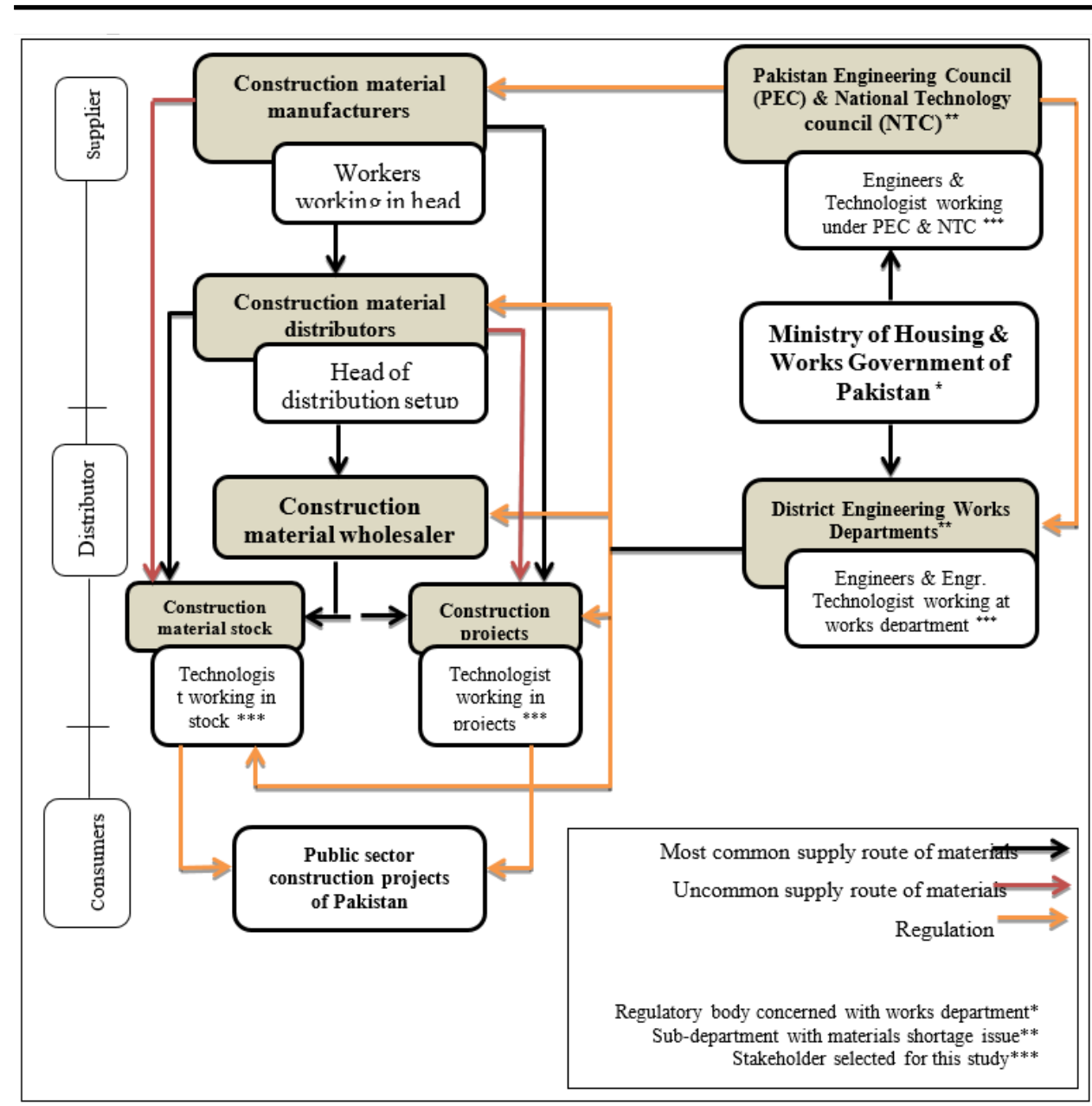

Figure 1. Material supply chain and concerned stakeholder in Pakistan

Engineers \& Engineering Technologists dealing with materials shortages are working under the affilations of Pakistan Engineering Council (PEC) \& National Technology Council (NTC). In this study, interviews and opinions were recorded from the members of PEC, NTC, and Engineering Work Department, Peshawar. Further, representatives of manufacturing companies were approached in Islamabad and Peshawar. The Lahorebased raw material manufacturing companies have their head offices in Islamabad, their representative was contacted there. Practically the entireties of the material organizations have their conveyance arrangement in Peshawar. Subsequently, for a talk with purposes, pertinent people were enquired to collect the important information for the exploration reason. 


\section{Research Objectives}

The examination goal of this investigation was to investigate the current circumstance and foundations for material deficiencies alongside the potential answers to overcome the hindrances. Also, some portion of this investigation was engaged to investigate the lack of specific construction material.

\section{Study Plan and Stakeholders Determination}

In this research study, a qualitative research study was utilized. The reason that issue should have been examined profoundly in Pakistan instead of just the evaluation of material deficiencies. To accomplish the research study objectives, semi-structured interviews were conducted though pilot study. The most applicable key sources were chosen depending on present literature (Sial et al., 2013) and afterward, interviewees were chosen carefully. All the partners were invited to take an interest in the examination through calls, and additional data, concerning the investigation, was given to them on demand via email.

Table 1. Respondents Characteristics and Interview Duration

\begin{tabular}{|c|c|c|c|c|c|c|c|c|c|}
\hline Stakeholders & Nos & Gender & Age & $\begin{array}{l}\text { Interview } \\
\text { duration } \\
\text { (min:sec) }\end{array}$ & Stakeholders & Nos & Gender & Age & $\begin{array}{c}\text { Interview } \\
\text { duration } \\
\text { (min:sec) }\end{array}$ \\
\hline $\begin{array}{l}\text { Works } \\
\text { Department }\end{array}$ & 1 & Male & 36 & $0: 25: 35$ & $\begin{array}{l}\text { Material } \\
\text { manufact } \\
\text { urer }\end{array}$ & 22 & Male & 36 & $0: 39: 40$ \\
\hline \multirow[b]{13}{*}{$\begin{array}{l}\text { Material } \\
\text { Distributor }\end{array}$} & 2 & Male & 38 & $0: 27: 40$ & \multirow[b]{10}{*}{ Supplier } & 23 & Male & 38 & $0: 41: 50$ \\
\hline & 3 & Male & 40 & $0: 35: 45$ & & 24 & Male & 40 & $0: 45: 42$ \\
\hline & 4 & Male & 45 & $0: 32: 20$ & & 25 & Male & 45 & $0: 30: 34$ \\
\hline & 5 & Male & 47 & $0: 20: 50$ & & 26 & Male & 47 & $0: 27: 40$ \\
\hline & 6 & Male & 40 & $0: 30: 40$ & & 27 & Male & 40 & $0: 35: 45$ \\
\hline & 7 & Male & 35 & $0: 40: 10$ & & 28 & Male & 35 & $0: 32: 20$ \\
\hline & 8 & Male & 32 & $0: 31: 15$ & & 29 & Male & 40 & $0: 20: 50$ \\
\hline & 9 & Male & 39 & $0: 15: 45$ & & 30 & Male & 45 & $0: 30: 40$ \\
\hline & 10 & Male & 43 & $0: 39: 40$ & & 31 & Male & 47 & $0: 40: 10$ \\
\hline & 11 & Male & 44 & $0: 41: 50$ & & 32 & Male & 43 & $0: 31: 15$ \\
\hline & 12 & Male & 50 & $0: 45: 42$ & \multirow[t]{12}{*}{ (2) } & 33 & Male & 44 & $0: 15: 45$ \\
\hline & 13 & Male & 51 & $0: 30: 34$ & & 34 & Male & 43 & $0: 39: 40$ \\
\hline & 14 & Male & 47 & $0: 27: 40$ & & 35 & Male & 44 & $0: 41: 50$ \\
\hline & 15 & Male & 40 & $0: 35: 45$ & & 36 & Male & 50 & $0: 45: 42$ \\
\hline & 16 & Male & 38 & $0: 32: 20$ & & 37 & Male & 51 & $0: 30: 34$ \\
\hline & 17 & Male & 40 & $0: 20: 50$ & & 38 & Male & 47 & $0: 27: 40$ \\
\hline & 18 & Male & 45 & $0: 30: 40$ & & 39 & Male & 45 & $0: 35: 45$ \\
\hline & 19 & Male & 47 & $0: 40: 10$ & & 40 & Male & 35 & $0: 32: 20$ \\
\hline & 20 & Male & 43 & $0: 31: 15$ & & 41 & Male & 32 & $0: 32: 20$ \\
\hline & 21 & Male & 44 & $0: 15: 45$ & & 42 & Male & 31 & $0: 20: 50$ \\
\hline & & & & & & 43 & Male & 50 & $0: 30: 40$ \\
\hline & & & & & & 44 & Male & 51 & $0: 40: 10$ \\
\hline
\end{tabular}

Face-to-face interviews were taken from the individuals who were happy to impart their insight and encounters with the researcher except for the agents of material producers 


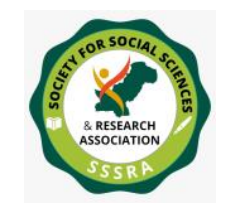

Pak. Journal of Int'L Affairs, Vol 4, Issue 1 (2021) Shortage of Construction Materials ...

who were contacted virtually. The members were met at a spot helpful to them. The example size was controlled by utilizing the immersion point models (Padawangi, 2010).

\section{Data Collection and Interview Pattern}

The data was collected gradually from January to March 2021. Initially, in January 2020, interviews were taken from the regulatory authorities for the technical worker registered with PEC and NTC and the representative of the manufacturers of construction materials. While In February 2021, the regulatory agencies of the Department of Engineering in Peshawar and material dealers were interviewed. In March 2021, engineering technologists who participated in public sector projects and materials inventories were interviewed. After reviewing the authors' literature and experiences, an interview schedule was created for each stakeholder. The interview plans were changed by a fundamental interview with a delegate from every one of the four gatherings. The last framework of the meeting included inquiries concerning essential data about the respondents and their association, the general situation of the deficiency of materials, the hidden reasons, and the potential arrangements and elements that added to the lack of certain development materials.

\section{Data Analysis}

Sound recorded phone calls were broken down utilizing inductive topical investigation. All the interviews were led in Urdu, the national language of Pakistan, and afterward, the sound chronicles were heard on various occasions and deciphered. The transcripts have been carefully translated into English and some transcripts (20\%) have used a back and forth translation method to verify the accuracy of the data. Interpretations were focused again and again to acclimatize themselves with the information. Pertinent words, expressions, and sentences recognizing the investigation destinations were distinguished and introductory inductive codes were produced to isolate the information into independently coded portions. The codes that rose out of the first interviews shaped a coding scientific classification that was utilized to assess the resulting interviews. Beginning coding was trailed by centered coding. On account of centered coding, the connection between the diverse starting codes was analyzed dependent on closeness, distinction, recurrence, succession, correspondence, and cause (Shah et al., 2011; Hussain et al., 2018). Each response was assessed once per respondent and the finding uncovered by the greater part of the respondents was seen as a critical finding. The examination had ordinary gatherings and conversations to confirm if they had a typical point of view and comprehension of the produced classes. In the event of contention or difference, the last 


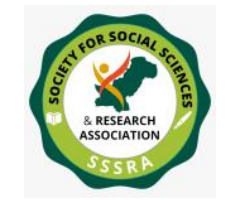

Pak. Journal of Int'L Affairs, Vol 4, Issue 1 (2021) Shortage of Construction Materials ...

judgment has been given. The outcomes were positioned by the determined recurrence in slipping requests, and afterward, the outcomes were composed to deliver the last report.

\section{Results}

Among all the selected respondents invited to take part in the examination; five couldn't partake (13\% dismissal rate) since they had a great deal to do and were not inspired by the investigation. A total of 44 stakeholders were interviewed, including 13 engineers, 10 manufacturers, 8 distributors, and 13 suppliers. The interview lasted between 15 and 41 minutes with an average duration of 35 minutes. All respondents were male and the allout number of members was 44 . The ages of the members went from 25 to 51 years. The characteristics of the respondents are given in Table 1. Four key topics were drawn from a group of saturated information, namely the current material shortage situation in Pakistan, its reasons, possible solutions to material shortage.

\subsection{Topic 1: Current Circumstance of Material Deficiencies in Pakistan}

Stakeholders utilized different terms to depict material deficiencies, including a deficiency gracefully of material, an irregularity among flexibly and request, and the inaccessibility of material over some time. Almost all the participants stated that they had seen the situation in the last four months when materials were scarce in the market and construction projects. The essential and precise material was short. All regulators and some manufacturers said they had found a way to forestall material deficiencies, while distributors said they were debilitated. When getting some information about the warning framework, most regulators said they had gotten or sent a deficiency notice, while one of the regulators and wholesalers announced a suitable notice framework.

\subsection{Topic 2: Reasons for Material Shortages}

Participants gave various and complex reasons for the shortage of material at different levels. At the manufacturer level, most participants stated that the main reason for the material shortage was relevant to raw material issues; including bringing in crude material issues, accessibility issues, evaluating, and portion allotment for crude materials controlled, just as arranging and figure holes. At the business level, the principal reason announced by the respondents was an inconsistent or deficient graceful item to makers, and the other explanation given was the slanted appropriation of short items. In the project condition, most members portrayed poor stock administration and acquisition techniques. Subsequently, the components that added to poor stock administration were poor interest gauging, poor acquirement, the plundering of materials, and poor stockpiling conditions. Participants featured different issues, for example, spending imperatives and postponed quality control testing. Because of the properties of the item 
advertised the low cost and low interest were the principal purposes behind the absence of materials.

\subsection{Topic 3: Potential Arrangements of the Material Deficiencies}

Everyone involved made practical suggestions to reduce the lack of construction materials. They recognized that the government has the authority to solve this problem. Most respondents suggested that makers ought to be upheld, spurred, and directed by the administration for the consistent creation and gracefulness of materials. The primary arrangements proposed by the majority of the members were satisfactory costs and the foundation of an administration hold framework for materials. At the maker level, the accessibility of substitute crude materials was the arrangement recommended by most respondents. Numerous witnesses additionally proposed that makers ought to guarantee the accessibility of financially and economically non-practical items for moral reasons. As per most of the participants, the arrangements most of the time proposed at the business level were the advancement of fair-minded deals frameworks, solid and sound association of merchants with producers, gracefully chain the board, great stockpiling rehearses, and the expansion in human and financial assets. In public sector projects, improving the stock control framework, allotting extra assets, and fortifying the provider job were a portion of the potential answers to maintain a strategic distance from the issue of material deficiencies.

\begin{tabular}{|c|c|c|}
\hline S.No & Cateoory & 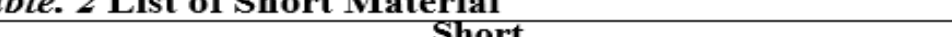 \\
\hline 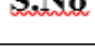 & Category & Material \\
\hline 1 & $\begin{array}{l}\text { Manufacturing } \\
\text { Unit }\end{array}$ & $\begin{array}{r}\text { Cement, steel rolling mills, steel foundries, glass factory, } \\
\text { the aluminum industry, crush plant and batching plant }\end{array}$ \\
\hline 2 & PVC & $\begin{array}{l}\text { UPVC industry, aluminum industry, and sanitary ware } \\
\text { factory }\end{array}$ \\
\hline 3 & $\begin{array}{c}\text { Electric } \\
\text { appliances }\end{array}$ & $\begin{array}{c}\text { Electric pumps, motor manufacturing, electric main DM } \\
\text { manufacturing, electric cables appliances, and fixtures } \\
\text { industry, and Fiberglass }\end{array}$ \\
\hline 4 & Reinforcement & $\begin{array}{c}\text { GI, CI, MS, HT, steel reinforcement, GI sheet, RS joints, T- } \\
\text { iron, Girders, and ceiling appliances }\end{array}$ \\
\hline 5 & Cast in-situ & $\begin{array}{c}\text { Precast concrete appliances and Precast concrete block } \\
\text { factory, precast RCC pipe factory, and prestressed } \\
\text { RCC/Tuff } \\
\text { Tiles }\end{array}$ \\
\hline 6 & $\begin{array}{c}\text { Miscellaneous } \\
\text { material }\end{array}$ & $\begin{array}{l}\text { Building safety equipment, shuttering material, drillingand } \\
\text { tube well accessories, solar equipment/batteries, chemicals, } \\
\text { rubber, mine and minerals equipment, Hi-tech equipment, } \\
\text { and brick } \\
\text { kiln }\end{array}$ \\
\hline
\end{tabular}


Table 3 demonstrates the most widely recognized answers to beat the material deficiency. Among the most widely recognized arrangements, 28 members showed that manufacturers ought to get backing, inspiration, and guidelines to take care of the issue, while 25 members demonstrated that the appropriation framework ought to be endorsed and improved conventionally to take care of the issue of material deficiencies.

Table 3: Most Regular Determinations for Materials Deficiencies (referenced by over 17 respondents

\begin{tabular}{|c|c|c|}
\hline S.N0 & Reasons for shortage & $\mathbf{n}^{*}$ \\
\hline 1 & Crude material-related issues & 36 \\
\hline 2 & $\begin{array}{c}\text { Absence of conventional } \\
\text { appropriation framework }\end{array}$ & 31 \\
\hline 4 & $\begin{array}{c}\text { Unexpected stock administration } \\
\text { and acquisition technique }\end{array}$ & 27 \\
\hline 5 & $\begin{array}{c}\text { Items financial related } \\
\text { non-suitability or low cost }\end{array}$ & 25 \\
\hline 6 & Marketing affected endorsing & 17 \\
\hline 7 & Production obstacles & 22 \\
\hline
\end{tabular}

Source: Own creation.

$\left(n^{*}\right)$ alludes to the recurrence of the reasons announced among respondents in general. Every reaction was evaluated once per respondent.

Table 4: Most basic arrangements of materials deficiencies (referenced by
\begin{tabular}{|c|c|c|}
15 respondents) \\
\begin{tabular}{|c|c|c|}
\hline S.No & Potential responses for material deficiencies & $\mathbf{n}^{*}$ \\
\hline 1 & $\begin{array}{c}\text { Manufacturers ought to be encouraged, } \\
\text { roused and controlled }\end{array}$ & 28 \\
\hline 2 & $\begin{array}{c}\text { Value exchange and obsession by the } \\
\text { administrative bodies }\end{array}$ & 25 \\
\hline 3 & An improved stock control framework & 19 \\
\hline 4 & Improved distribution framework & 15 \\
\hline 5 & Advancement of customary dispersion \\
framework
\end{tabular} & \\
\hline
\end{tabular}

Source: Own creation.

$\left(n^{*}\right)$ alludes to the recurrence of the reasons detailed among respondents

overall. Every reaction was measured once per respondent. 


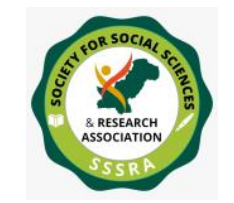

\section{Discussion}

Sector construction and material deficiencies are as often as possible rising worldwide marvel representing the danger of a huge task to the legislature just as on the private business (Sadiq, 2010). The American Standard Testing Material (ASTM) expressed those material deficiencies as a less-examined issue in low and middle-income nations (Kim et al., 2016). This is the main subjective investigation to increase a top to bottom comprehension of perplexing and multifaceted material deficiencies issues in Pakistan. In this examination, topics featured the current situation of material deficiencies in Pakistan, its reasons, and potential arrangements, and the specific development brand lack issues.

In this investigation, various sorts of phrasings were utilized by the members to portray the material deficiencies, and all wordings were practically identical with the meanings of material deficiencies given by the ASTM (Frimpong et al., 2003). For instance, our respondents expressed that material lack is the hole between the interest and flexibility or creation, inaccessibility of item at some random time, and inaccessibility of material for every single whole routine. In like manner, a European report expressed that material deficiencies could be communicated as request and gracefully unevenness or interfered with flexibility or the inaccessibility of material to fulfill the project needs (Shah et al., 2018). As indicated by the aftereffects of our investigation, deficiencies of fundamental development material and lifeagreeable material were visited during the most recent year in Pakistan. The past dim writing reports additionally showed a deficiency of life-agreeable development material and fundamental material for human life in the nation (Haseeb et al., 2011; Al-Kharashi \& Skitmore, 2009). The gap in basic material access is driven by a wasteful Pakistani designing commission framework and development material guidelines, which requires multidimensional incorporated ways to deal with a guarantee of the accessibility of materials (Mezher \& Tawil, 1998). These revelations were synchronous with the typology of material insufficiency presented by the Chinese and European assessments (Assaf et al., 1995; Aibinu \& Odeyinka, 2006). Our respondents clarified that no single perspective can be considered as a clarification of material lacks. Among various uncovered reasons, the huge clarification was unrefined material-related issues including its import impediments, detachment, noteworthy cost, and constrained offer bit. As demonstrated by a report, material insufficiency occurred in the UAE on account of the break in the rough material effortlessly because $80 \%$ of it was 


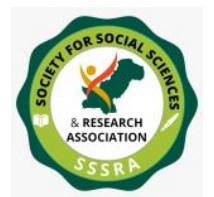

imported from abroad (Assaf et al., 1995). The reasons for inaccessibility of crude material could be constrained suppliers or manufacturers of crude material, political clashes prompting import obstacles, administrative limitations on the import and distribution of controlled substances, long conveyance time, issues in the extraction of crude material because of the ecological changes, complex creation chain, quality issues, and issues in the vehicle and stock (Al-Khalil \& Al-Ghafly, 1999; Sambasivan \& Soon, 2007). In Pakistan, the greater part of the crude materials and dynamic development fixings are imported from India, China, Europe, the USA, and middle-eastern nations (Chan \& Kumaraswamy, 1997). As indicated by news reports, an expansion in the estimation of the US dollar vis-a-vis Pakistani rupees brought about expanded expense of crude material and ensuing deficiencies of effectively available material (Koushki \& Kartam, 2004; Bruce, 2001). Poor stock administration and acquisition strategy were other purposes behind the material lack in the Pakistani construction industry. Numerous past investigations including a Pakistani report featured that stock blunder was one of the central point's sabotaging the material access in projects (Shree, 2007; Schumacher, 1996). As per the reports, contributing variables in the poor stock administration could be an insufficient financial plan, customer inclinations, constrained data sharing, and absence of the dynamic job of an engineer and engineering technologist (Al-Sultan, 1989; Asadi et al., 2015). While poor acquirement could be because of deferrals in the offering, nonattendance of temporary workers and lack of ability of the suppliers to satisfy the request (Kenny \& Vanissorn, 2012), on account of our examination members, the subsequent significant purpose behind material deficiencies in the project setting was spending requirements. In like manner, a previous report uncovered that insufficient financing or poor spending of the board was a purpose behind the poor accessibility of the material in the Pakistani construction industry (Gunduz et al., 2015). Other than this, wasteful spending of the board further worsens this issue in the nation (Arditi et al., 1985). Different components add to wasteful budget management, including insufficient interest forecast, poor acquisition, material pilferage, and inaccessibility or need dynamic support of suppliers (Assaf \& Al-Hejji, 2006). The assessment of members considered to be as having the ability to decide the material lacks issue. Among the proposed courses of action, the most noteworthy were the help and rule of makers and improved stock control systems in projects. The administration should rapidly immediately and attach the makers to ensure the availability of material and should resolve their issues. The ASTM has moreover thought about the rule and help of makers as one of the flashing key plans for thwarting and reducing material insufficiency (Faridi \& Sayegh, 2006; Ling \& Hoi, 2006). Be that as it may, 


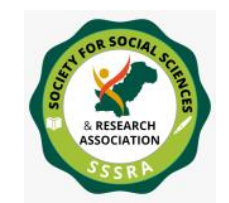

as of late in January 2020, considered the present circumstance of material deficiencies in the nation and its related complex reasons, for example, the $33 \%$ degrading of Pakistani Rupee against the US dollar and along these lines expanding estimating of crude and bundling materials. This remedial measure is relied upon to quickly address material deficiencies problems inside the nation. To forestall material deficiencies in the construction industry, participants of this examination recommended the improvement in stock administration as an answer through the dynamic support of suppliers in estimating, acquisition, and item determination. Besides, suppliers must furnish themselves with extra abilities and mastery expected to adapt to material deficiencies. (El-Razek et al., 2008; Iqbal et al., 2015). A Pakistani report revealed that a deficiency of specific construction brands of the material was generally high (Lo et al., 2006; Okpala \& Aniekwu 1988). The author investigated this issue and discovered some particular reasons and potential answers for specific material lack. The respondents finished up, that the absence of customary dispersion framework and subsequent unlawful works on, including equal exchange, fake deficiency, dim market, and specific appropriation was the main and fervently contended purposes behind material deficiencies. The Pakistani report revealed that a deficiency of specific construction brands of the material was generally high (Lo et al., 2006; Okpala \& Aniekwu 1988).

The researcher investigated this issue and discovered some particular reasons and potential answers for specific things that lack. The respondents finished up, that the absence of customary dispersion framework and subsequent unlawful works on, including equal exchange, fake deficiency, dim market, and specific appropriation was the main and fervently contended purposes behind material deficiencies. The main purpose of this deceptive practice is to procure high money-related advantages at the expense of critical danger to the construction industry. Comparable reasons for material deficiencies were accounted for in European examinations. An investigation, evaluating the material deficiencies in the UK and European nations, likewise uncovered that material deficiencies were activated by sudden variance sought after. As per this investigation, the lack of a specific developmental material was likewise exceptionally effected by the recommending design. The stakeholder's additionally uncovered exploitative limited-time promoting methodologies and motivators to be the explanation of expert contemptibly.

In the Pakistani setting, the construction industries spend a ton of cash on limited-time methodologies (Mansfield, 1994; Olawale \& Sun, 2010). The past Pakistani investigations have likewise been thought to be limited-time, 


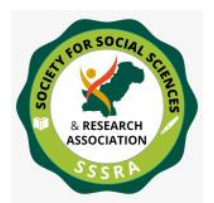

Pak. Journal of Int'L Affairs, Vol 4, Issue 1 (2021) Shortage of Construction Materials ...

impacted endorsing of specific materials brand as one of the significant hindrances in the entrance to the material (Doloi et al., 2012; Al-Hammad, 1993). Creation obstacles, including constrained creation limit, creation breakdown, and issues in the assembling chain were additionally most often found as the reason behind specific material deficiencies in this investigation. Numerous past examinations have announced assembling obstacles as one of the reasons for the inaccessibility of material in the market. Stakeholders thought the advancement of customary dispersion was a required measure to forestall a deficiency of specific things of material. The ASCE featured as well as stressed the advancement of conventional circulation frameworks through the foundation and execution of rules and exacting approaches (Morris \& Geraldi, 2011). This examination effectively assessed the circumstances concerning the material deficiencies in Pakistan while facing a few constraints simultaneously. Notwithstanding, a wide scope of stakeholders were included and remembered for the investigation. In this way, our center was more towards investigating the explanation and potential arrangements of the material deficiencies from a graceful point of view which can be better tended to at the government and material assembling level (Ali et al., 2020). Other than this, distributors and suppliers were remembered for the investigation since they were responsible for the material gracefulness and the executives of inventories in both the open division and the private area of the construction industry. In any case, to limit the potential predisposition and guarantee similar results, a total respondent data pack (counting interview schema) was given to them before the interview. Therefore, the researcher found that assented manufacturers were truly agreeable and transparently gave realities when they were guaranteed of their obscurity. 


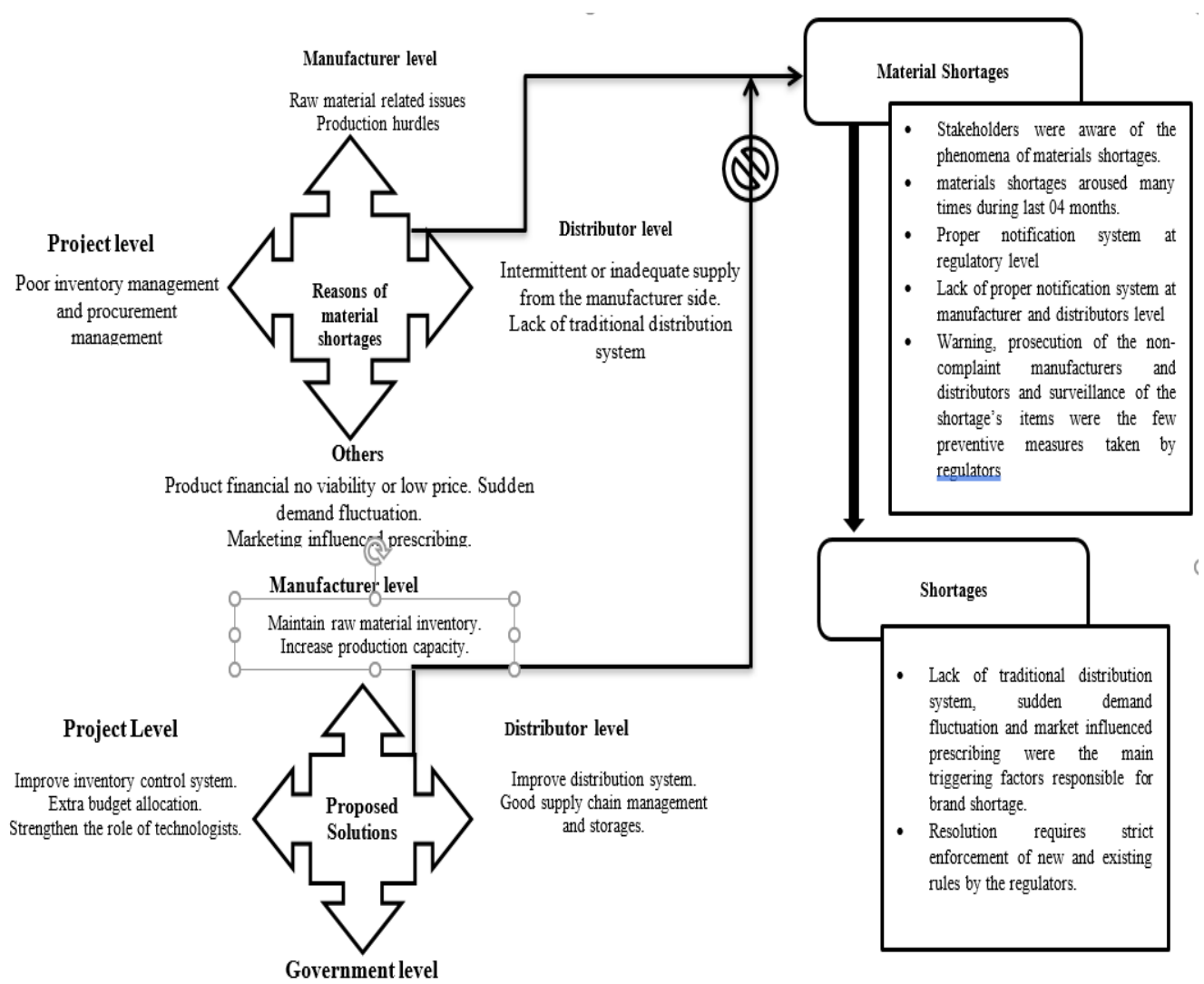

Manufacturers should be facilitated, motivated, and regulated. Price negotiation are fixing by the regulatory bodies. Promotion of traditional distribution system. Establish reserve system of material.

\section{Conclusions}

This research project aimed was to dig out the possible reasons for the shortage of construction material in Pakistan's three major cities named Lahore, Islamabad, and Peshawar. The logic behind conducting this study is to discover remedies to avoid the shortage of construction materials. The study finds out the fundamental reasons responsible for deficiencies of crude materials and also proposed remedies.

It is found out that deficiency of a customary delivery system, unexpected fluctuations in demand, import obstacles, inaccessibility, significant expense, and limited share portion in raw material, constrained suppliers or manufacturers of crude material, political 


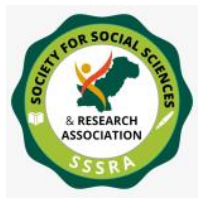

clashes prompting import obstacles, regulatory constraints on the import and appropriation of controlled substances, long movement time, issues in the extraction of rough material are related with the deficiency of materials. In the light of the result obtained, the recommended remedies are to extend flexibility and guideline for the manufacturers, the maintenance of realistic prices, and boosts in the record control system. Among the different arrangements proposed to avoid material, deficiencies are to encourage and direct manufacturers, settle on sensible value understandings, improve in the stock control framework, adequate prices, and establishment of a government reserve system for materials and at the market level, the accessibility of substitute crude materials.

\section{Recommendations}

Material shortage protocols are completely deficient in Pakistan. The consequences of this far-reaching and target research will assist policymakers with creating and keep up standard conventions, just as short and long-haul anticipation systems.

1. According to the results of this study, the lack of material could be limited through short and long-haul techniques.

2. The transient arrangement of materials, bottlenecks could be accomplished through assistance, inspiration, and the guideline of manufacturers, sensible estimating, the foundation of a material reservation framework, an extra portion of assets from the administration, and the support of the stock of crude materials.

3. To restrict the shortage of materials in the long term, the administration ought to advance customary deal frameworks, execute nonexclusive plans, build up improved stock control frameworks in projects, and reinforce the job of suppliers.

4. After understanding the full situation of material deficiencies in Pakistan, an agreeable institutional, project arranged, and social methodology are prescribed to effectively maintain a strategic distance from material deficiencies.

5. From an exploration perspective, this examination gives a strong premise for future multi-dimensional studies to all the more likely measure and further access the impacts, fundamental reasons, and potential answers for material deficiencies and to give policymakers constant criticism. 


\section{References}

Abdul-Rahman, H., Berawi, M. A., Berawi, A. R., Mohamed, O., Othman, M., \& Yahya, I. A. (2006). Delay Mitigation in the Malaysian Construction Industry. Journal of Construction Engineering and Management, 132(2), 125-133.

Ahmad, R., \& mohamad, N. A. (2014). Performance of Projects in Public Sector of Pakistan: Developing a Framework for Future Challenges, 4, 3-12.

Al-Kharashi, A., \& Skitmore, M. (2009). Causes of delays in Saudi Arabian public sector construction projects.Construction Management and Economics, 27(1), 3-23.

Assaf, S. A., Al-Khalil, M., \& Al-Hazmi, M. (1995).Causes of Delay in Large Building Construction Projects.Journal of Management in Engineering, 11(2), 45-50.

Al-Khalil, M. I., \& Al-Ghafly, M. A. (1999). Important causes of delay in public utility projects in Saudi Arabia.Construction Management and Economics, 17(5), 647-655.

Aibinu, A. A., \& Odeyinka, H. A. (2006). Construction Delays and Their Causative Factors in Nigeria.Journal of Construction Engineering and Management, 132(7), 667-677.

Al-Sultan, A. S. (1989). Determination of construction contract duration for public projects in Saudi Arabia (Doctoral dissertation, King Fahd University of Petroleum and Minerals).

Asadi, A., Alsubaey, M., \& Makatsoris, C. (2015). A machine learning approach for predicting delays in construction logistics. International Journal of Advanced Logistics, 4(2), 115-130.

Arditi, D., Akan, G. T., \& Gurdamar, S. (1985). Reasons for delays in public projects in Turkey. Construction Management and Economics, 3(2), 171-181.

Assaf, S. A., \& Al-Hejji, S. (2006). Causes of delay in large construction projects. International Journal of Project Management, 24(4), 349-357.

Abd El-Razek, M. E., Bassioni, H. A., \& Mobarak, A. M. (2008). Causes of Delay in Building Construction Projects in Egypt. Journal of Construction Engineering and Management, 134(11), 831-841. 


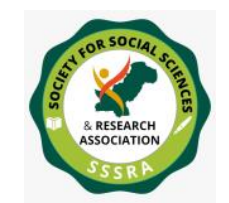

Pak. Journal of Int'L Affairs, Vol 4, Issue 1 (2021) Shortage of Construction Materials ...

Al-Hammad, A. (1993). Factors affecting the relationship between contractors and their sub-contractors in Saudi Arabia: About 70\% of contract work is subcontracted in Saudi Arabia, this paper highlights literature search and pilot interview findings. Building Research \& Information, 21(5), 269-273.

Ali, M., Iqbal, S., Iqbal, Q. (2020). Causes of Delay in the Establishment of Public Sector University in Newly Merged District of KP Pakistan. International Journal of Engineering Works, 07(05), 221-227.

Bruce, D. (2001). Help wanted: Results of CFIB surveys on the shortage of qualified labour. Canadian Federation of Independent Businesses.

Chan, D. W., \& Kumaraswamy, M. M. (1997). A comparative study of causes of time overruns in Hong Kong construction projects. International Journal of Project Management, 15(1), 55-63.

Doloi, H., Sawhney, A., Iyer, K. C., \& Rentala, S. (2012). Analysing factors affecting delays in Indian construction projects. International Journal of Project Management, 30(4), 479-489.

Frimpong, Y., Oluwoye, J., \& Crawford, L. (2003). Causes of delay and cost overruns in construction groundwater projects in a developing countries; Ghana as a case study. International Journal of Project Management, 21(5), 321-326.

Faridi, A. S., \& El-Sayegh, S. M. (2006). Significant factors causing delay in the UAE construction industry. Construction Management and Economics, 24(11), 1167-1176.

Gunduz, M., Nielsen, Y., \& Ozdemir, M. (2015). Fuzzy Assessment Model to Estimate the Probability of Delay in Turkish Construction Projects. Journal of Management in Engineering, 31(4), 04014055.

Hwang, B.-G., Zhao, X., \& Ng, S. Y. (2013). Identifying the critical factors affecting schedule performance of public housing projects. Habitat International, 38, 214-221.

Hussain, S., Zhu, F., Ali, Z., Danial Aslam, H., \& Hussain, A. (2018). Critical delaying factors: Public sector building projects in GilgitBaltistan, Pakistan, 8(1), 6.

Haseeb, M., Xinhai, L., Bibi, A., ud-Dyian, M., \& Rabbani, W. (2011). Causes and Effects of Delays in Large Construction Projects of Pakistan, 1(4), 41-50.

Iqbal, S., Choudhry, R. M., Holschemacher, K., Ali, A., \& Tamošaitienè, J. (2015). RISK MANAGEMENT IN 


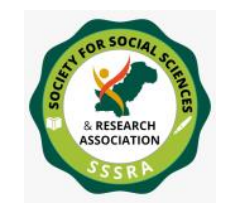

Pak. Journal of Int'L Affairs, Vol 4, Issue 1 (2021) Shortage of Construction Materials ...

CONSTRUCTION PROJECTS. Technological and Economic Development of Economy, 21(1), 65-78.

Iyer, K. C., \& Jha, K. N. (2005). Factors affecting cost performance: Evidence from Indian construction projects. International Journal of Project Management, 23(4), 283-295.

Kim, S.-Y., Tuan, K. N., Lee, J. D., Pham, H., \& Luu, V. T. (2018). Cost overrun factor analysis for hospital projects in Vietnam. KSCE Journal of Civil Engineering, 22(1), 1-11.

Kim, S.-Y., Tuan, K. N., \& Luu, V. T. (2016). Delay factor analysis for hospital projects in Vietnam. KSCE Journal of Civil Engineering,20(2), 519-529.

Koushki, P., \& Kartam, N. (2004). Impact of construction materials on project time and cost in Kuwait, 11, 126-132.

Kenny, W., \& Vanissorn, V. (2012). A study of the factors affecting construction time in Western Australia. Scientific Research and Essays, 7(40), 3390-3398.

Ling, F. Y. Y., \& Hoi, L. (2006). Risks faced by Singapore firms when undertaking construction projects in India. International Journal of Project Management, 24(3), 261-270.

Lo, T. Y., Fung, I. W., \& Tung, K. C. (2006). Construction Delays in Hong Kong Civil Engineering Projects. Journal of Construction Engineering and Management, 132(6), 636-649.

Morris, P. W. G., \& Geraldi, J. (2011). Managing the Institutional Context for Projects. Project Management Journal, 42(6), 20-32.

Mansfield, N., Ugwu, O., \& Doran, T. (1994). Causes of delay and cost overruns in Nigerian construction projects. International Journal of Project Management, 12(4), 254-260.

Mezher, T. M., \& Tawil, W. (1998). Causes of delays in the construction industry in Lebanon. Engineering, Construction and Architectural Management, 5(3), 252-260.

Mahmood, S. (2001). The Musharraf regime and the governance crisis: a case study of the government of Pakistan. Nova Publishers.

Olawale, Y. A., \& Sun, M. (2010). Cost and time control of construction projects: Inhibiting factors and mitigating measures in practice. Construction Management and Economics, 28(5), 509526.

Okpala, D. C., \& Aniekwu, A. N. (1988). Causes of High Costs of Construction in Nigeria. Journal of Construction Engineering and Management, 114(2), 233-244. 


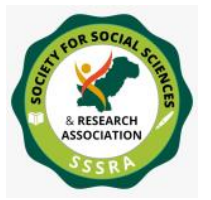

Pak. Journal of Int'L Affairs, Vol 4, Issue 1 (2021) Shortage of Construction Materials ...

Padawangi, R. (2010). Community-driven development as a driver of change: water supply and sanitation projects in rural Punjab, Pakistan. Water Policy, 12(S1), 104-120.

Rehman, A. U., Khan, A. M., \& Khan, R. A. (2011). Measuring Training Effectiveness: A Case Study of Public Sector Project Management In Pakistan. Journal of Diversity Management (JDM),6(1).

Rahman, I. A., Hameed Mem, A., \& Abd. Karim, A. T. (2013). Significant Factors Causing Cost Overruns in Large Construction Projects in Malaysia. Journal of Applied Sciences, 13(2), 286-293.

Sweis, G., Sweis, R., Abu Hammad, A., \& Shboul, A. (2008). Delays in construction projects: The case of Jordan. International Journal of Project Management, 26(6), 665-674.

Sial, A., Usman, M. K., Zufiqar, S., Satti, A. M., \& Khursheed, I. (2013). Why do public sector organizations fail in implementation of strategic plan in Pakistan. Public Policy and Administration Journal, 3(1), 33-41.

Shah, S. I. H., Bokhari, R. H., Hassan, S., Shah, M. H., \& Shah, M. A. (2011). Socio-technical factors affecting ERP implementation success in Pakistan: an empirical study. Australian Journal of Basic and Applied Sciences, 5(3), 742-749.

Sadiq, M. (2010) Determinants of Poverty in Pakistan. hamburg review of social sciences, 4(3) 193-213.

Shah, S. A., Balasingam, U., \& Dhanapal, S. (2018). Legal Education in Pakistan: An Overview. IIUM Law Journal, 26(2), 401.

Sambasivan, M., \& Soon, Y. W. (2007). Causes and effects of delays in Malaysian construction industry. International Journal of Project Management, 25(5), 517-526.

Shree, S. (2007). Equipment rentals hit construction industry. Live Mint.

Schumacher, L. (1996). An integrated and proactive approach for avoiding delay claims on major capital projects. Cost Engineering, 38(6), 37.

Wei, K. S. (2010). Causes, effects and methods of minimizing delays in construction projects. A project report. 